\title{
SOLUTION OF FIRE PROTECTION IN HISTORIC BUILDINGS
}

\author{
Agnes IRINGOVÁ ${ }^{1, *}$, Róbert IDUNK ${ }^{2}$ \\ 1 Department of Building Constructions and Urban Planning, Faculty of Civil Engineering, University of \\ Žilina, Univerzitná 8215/1, 01026 Žilina, Slovakia. \\ 2 Department of Structures and Bridges, Faculty of Civil Engineering, University of Žilina, Univerzitná \\ 8215/1, 01026 Žilina, Slovakia. \\ corresponding author: agnes.iringova@fstav.uniza.sk.
}

\begin{abstract}
The paper introduces optimization of the functional use of renovated spaces in historic buildings in terms of fire risk. It brings assessment of fire protection in the folk house Habánsky Dvor, situated in the village of Vel'ké Leváre, whose function was changed into the museum. It goes into static analysis of existing load-bearing structures and assessment of their fire resistance according to Eurocodes.
\end{abstract}

\section{Keywords:}

Fire protection; Historic buildings; Hutterian museum; Static analysis.

\section{Introduction}

The paper deals with analysis of fire protection in a historic building which is of combined construction system with horizontal load-bearing structures. It focuses on fire resistance assessment of existing timber load-bearing members in practical solution to restore a folk building in the area of the Hutterian Museum according to Eurocodes.

\section{Characteristics of historic roofs in terms of their shape, spatial usability, and element dimensions}

Roofs of historic buildings are primarily designed as self-supporting purlin systems which are usually structurally independent from the last floor. Depending on the building's size, there were often collar systems used - typical for ventricular architecture, or combinations of standing trestles with hanging trusses or strut frames for larger spans - manor houses, castles, churches.

Spatial usability of roof spaces, using built-in constructions, is the most optimal in collar systems. Structural systems with standing trestles seem to be more limited.

Truss structures and dimensions of their members were primarily based on spans they covered and technical capabilities of the builders. The design of members in supporting system was derived from graphic methods tested on models and subsequent evidence of their actual implementations. Due to technical joint possibilities that were available at that time and were principal for static load of purlin systems, the dimensions of timber elements have usually significant static margin. Joints of timber elements were generally tenoned or lapped, which required larger load-bearing surfaces and larger effectual cross-sections of individual elements as well. Dimensions of load-bearing truss elements were, in terms of static load, typically oversized by $30-70 \%$.

\section{Functional optimization of historic buildings considering fire risk}

As a result of economic evaluation of restored objects, there is often an investor's requirement to situate working rooms in the roof space using built-in constructions without changing the shape and structure of original trusses. In the restoration of historic buildings, material and spatial authenticity of all renewed members is very important, as well as it is necessary to take into account the operational requirements for their new functions in terms of changes of several physical parameters. The 
functional change of a building often brings a change in fire load, which increases requirements for fire resistance of load-bearing and partition structures.

In terms of planned changes, it is important for the planned operations to be in fire risk that doesn't fundamentally change the requirements for fire resistance of original structures. Requirements for fire resistance of structures are directly dependent on the building's fire height and flammability of its particular parts. When placing built-in constructions into historic trusses, there is always a change in the fire height that is usually followed by changes of the requirements for fire resistance of loadbearing and fire separating structures as well.

Historic buildings are assessed according to STN 73 0834/2010 "Changes of buildings" and subsequently according to STN 73 0802/2010 "Fire safety of non-production buildings including their changes".

The table below provides examples of the operations suitable for historic buildings in terms of fire hazard taking into account the fire protection. Their optimization depends on the building's fire height, which is the superelevation of the 1st-floor level up to the last-floor level on the last commercial floor. Such objects are typically of combined constructional system - masonry vertical structures and timber horizontal structures.

Table 1: Optimization of functional changes in historic buildings in terms of fire protection requirements for original structural elements.

\begin{tabular}{|c|c|c|c|c|c|c|c|c|c|}
\hline \multirow{3}{*}{$\begin{array}{c}\text { Fire } \\
\text { height }\end{array}$} & \multirow{3}{*}{$\begin{array}{c}\text { Functional } \\
\text { usability }\end{array}$} & \multicolumn{3}{|c|}{ Fire hazard } & \multirow{3}{*}{$\begin{array}{l}\text { Degree } \\
\text { of fire } \\
\text { safety }\end{array}$} & \multicolumn{4}{|c|}{$\begin{array}{c}\text { Requirements for fire-separating structures } \\
\text { in combined constructional system } \\
\text { on the 1st/last floor }\end{array}$} \\
\hline & & \multirow[t]{2}{*}{$a$} & \multirow[t]{2}{*}{$b$} & \multirow{2}{*}{$\begin{array}{c}p_{v} \\
\mathrm{~kg} / \mathrm{m}^{2}\end{array}$} & & walls & ceilings & roof & $\begin{array}{c}\text { Fire } \\
\text { dampers }\end{array}$ \\
\hline & & & & & & REI & REI & REI & El, EW \\
\hline \multirow{3}{*}{$\mathrm{ho}=0 \mathrm{~m}$} & Museums, galleries & 1.1 & 0.9 & 65 & II. & 15 & 15 & 15 & $15 \mathrm{C} 2$ \\
\hline & Libraries & 0.7 & 0.9 & 80 & II. & 15 & 15 & 15 & $15 \mathrm{C} 2$ \\
\hline & Coffee bars & 1.2 & 0.9 & 37 & I. & 15 & 15 & 15 & $15 \mathrm{C} 2$ \\
\hline \multirow{3}{*}{ ho $\leq 12 \mathrm{~m}$} & Accommodation & 1.0 & 0.8 & 35 & III. & $45 / 30$ & $45 / 30$ & 30 & $30 \mathrm{C} 2 / 15 \mathrm{C} 2$ \\
\hline & Administration & 1.0 & 0.8 & 35 & III. & $45 / 30$ & $45 / 30$ & 30 & $30 \mathrm{C} 2 / 15 \mathrm{C} 2$ \\
\hline & Education & 0.9 & 0.8 & 32 & III. & $45 / 30$ & $45 / 30$ & 30 & $30 \mathrm{C} 2 / 15 \mathrm{C} 2$ \\
\hline
\end{tabular}

The change of the fire height and functional usability causes different space occupancy and the category of evacuation routes. In multi-storey buildings, there are usually vertical communication cores that haven't enough space so their capacity is inadequate.

\section{The example of fire protection in a historic building}

\subsection{Layout of the building}

This chapter will describe the solution of fire protection in the restored building of the folk house Habánsky Dvor in the village of Velké Leváre. It used to be a family house of the Izers family.

The object is among the oldest sights of ventricular architecture in Slovakia. Its restoration was focused on preserving its original spatial authenticity, structural members, and beautiful handcrafted elements so that they could form a part of the exhibition to declare craftsmanship of the past.

The building is a part of period buildings surrounding the square and is built in the late Gothic style like houses in Germany. Such house type features a high roof with two-level collar beam. Hutterian houses used to have rectangle ground plans; the example given herein is $8.2 \mathrm{~m}$ wide and $21.8 \mathrm{~m}$ long. Daily part, situated on the ground floor, comprised a living room, kitchen, and housing for old family members.

An open wooden stairs led to the attic. Attic rooms were situated on either side of the corridor. The central corridor is $0.9 \mathrm{~m}$ wide. The $2 \mathrm{nd}$ floor was accessed via wooden stairs. This space was opened and probably served for the storage of goods and materials. 
The truss is a part of the fire section of the entire building. The structures in the building are original, except thatched roof which was replaced with ceramic tiles. The building was already renovated in the past, but currently the ground floor is used only. It houses the exposition of Hutterian crafts. Attic rooms have no functional use; they serve only to expose the original timber roof structure and layout - bedrooms of family members.

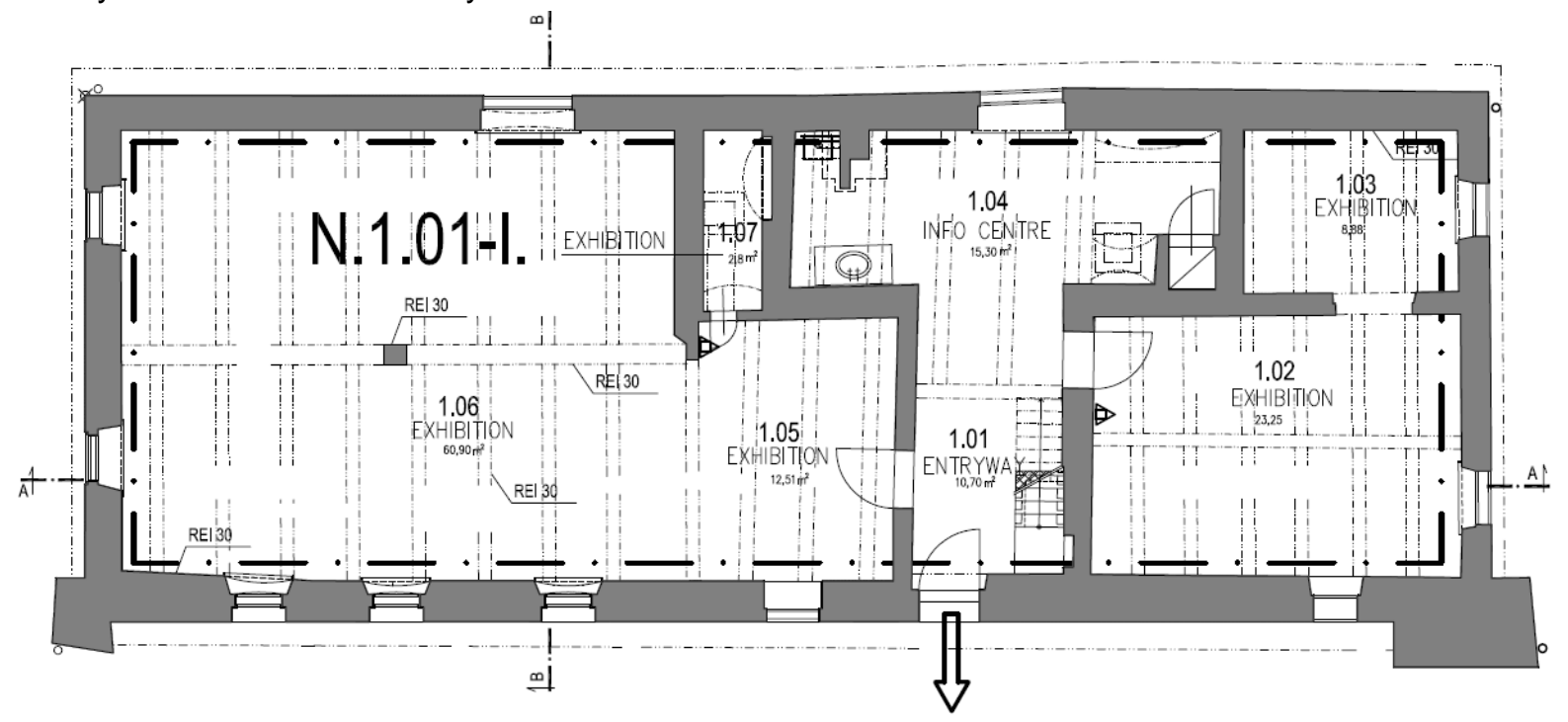

Fig.1: Layout of the 1st floor [8].

\subsection{Analysis of the structural system and building constructions}

The building is combined, mud-brick structure having $500-600 \mathrm{~mm}$ thick external walls. Partition walls on the ground floor are masonry, $300-450 \mathrm{~mm}$ thick. There is a joist ceiling above the ground floor. Beams carry the floor structure and serve as a lower stem for load-bearing truss system too. The living room takes the full width of the floor plan. In the living room, there are timbered ceiling beams supported with wooden bearer. It is fixed in the middle of the pillar and on wall edges. Steps are wooden, single-stringed, and $0.75 \mathrm{~m}$ wide.

Original interior walls in the attic were of mud-brick/wood combination. Currently, their wooden frame is only admitted. The floor is made of wooden decking with clay layer.

The roof is pitched with the wooden purlin system. Rafters are clipped with ceiling tie beams, central and top bonding tie.


Fig. 2: Longitudinal and cross section [8].

The original multi-layered thatched roof was covered with continuous clay layers. Straw served as a thermo-insulator and carrier for the clay. Its hollow stems prevented heat from flowing between the protected and external environment in winter as well as in summer. Since the roof slope was about $56.3^{\circ}$, rain water and snow run down very fast without any other effect to its waterproofing. Clay was also an excellent fire-insulator; it eliminated the fire spread from building to building by falling and flying burning pieces, or by thermal radiation from nearby burning sources. 
Assessment of fire safety in alternated buildings can employ tabular standard values specified in STN 730821 [13]. Their use, however, is possible only if the assessed structure is identical to the structure referred to in the standard. If structures are different in the cross-section or in values of static load specified in tables, which is this case, their fire resistance is assessed according to the relevant standard.

Fire resistance of building constructions is generally determined on the basis of puncture (initial) test in accordance with Statute 133/2013 Code [11], or by calculation according to the relevant technical standards, in dependence on its material solutions. In this particular case, timber structural elements are assessed according to STN EN 1991-1-1,2 [1]. Assessment is based on the specified criteria and time in minutes.

\section{Static assessment of load-bearing members in the Hutterian Museum at the room temperatu- re according to STN 1995-1-1 (Eurocode 5)}

Static assessment is focused on fundamental load-bearing elements of the timber roof and ceiling to ultimate load limit. It does not include assessment of carpentry joints and serviceability of the construction to limit state, because the existing building is fully used today.

The load-bearing truss structure has a triangular cross-section which is strutted with a collar beam at two levels. Bottom collar beams are supported with central purlins. They lie on the gable wall edges and timber pillars.

System rigidity in the transversal direction provides 3 full ties asymmetrically located. Longitudinal bracing is provided by the struts with longitudinal members and full decking at the level of collar beams and a roof plane. There are carpentry joints.

The computational model was created using the SciaEngineer software as a spatial FE model made of 1D-members. The main load-bearing members are jointed. Centre line rods, wherein distances occurred, were interconnected by solid bonds with single joints. The model is shown in Figure 3 a) and b).



a)

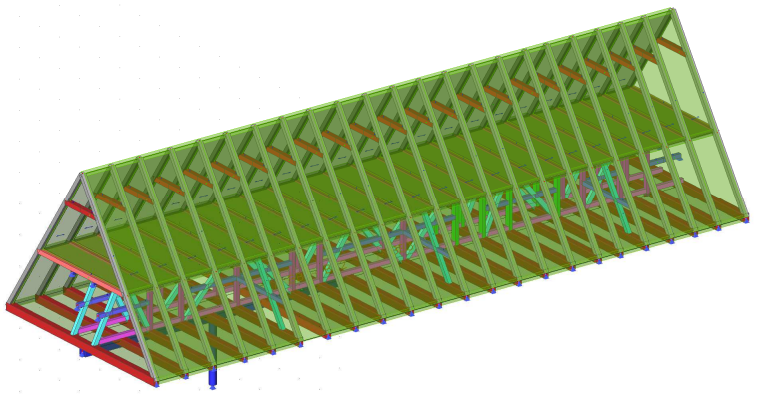

b)

Fig. 3: Computational model.

The load was calculated in accordance with [1], [2] and [3]. All effects, considered as the surface load, are as follows: net weight (generated by the program), permanent load (ceiling and collar beam $0.17 \mathrm{kN} / \mathrm{m}^{2}$, rafters $0.65 \mathrm{kN} / \mathrm{m}^{2}$ ), snow load $\left(0.06 \mathrm{kN} / \mathrm{m}^{2}\right.$ ), and wind load (for $0^{\circ}$ : from -0.2 to $0.46 \mathrm{kN} / \mathrm{m}^{2}$; for $90^{\circ}$ : from -0.53 to $-0.79 \mathrm{kN} / \mathrm{m}^{2}$ ). Snow was considered with and without snowdrift layout under the temporary or permanent planned condition. Above mentioned load is distributed using flat panels. Wood material characteristics used correspond to strength class C20 according to the standard [6]. The effect of load combination for the ultimate load state (ULS) is decisive according to EN-ULS (STR/GEO) B-Set generated automatically by the program.

Assessment of timber elements is made according to standards [4] using auto-reviews which are part of the SciaEngineer software. Assessment of particular elements is shown in Figure $4 \mathrm{a}$ ) and b). 


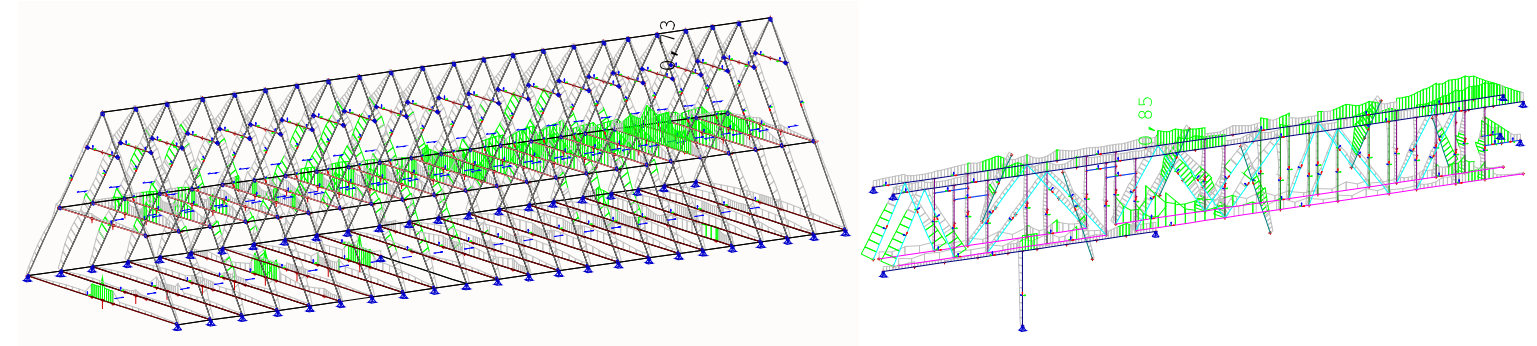

a)

b)

Fig. 4: Assessment of particular elements in the ULS.

Despite the fact that the structure is old, it meets the ULS within valid standards. Thus, the use of cross-sections does not exceed $85 \%$.

\section{Fire resistance calculation of structural members according to EN 1991-1-1-2}

Methods to calculate fire resistance of structures in terms of Euro codes employ the analytical approach to design buildings considering the fire effect. It takes into account the function of a structural system at higher temperatures in terms of static load of fire separating structures as well as increases in thermal protection by active or passive elements of fire protection systems. When designing or assessing load-bearing fire barrier according to EN 1991-1-2, the appropriate model of fire situation is chosen. Subsequently, the corresponding fire scenario is determined. The temperature course in load-bearing structural elements stressed both statically and thermally is calculated according to standard temperatures in the affected fire zone. The resulting static load of a structure in a critical fire situation is calculated and the cross-section is evaluated - whether it meets supposed thermal stress in the required time.

The mechanical behaviour of statically stressed structures during fire depends on thermal load defined by fire risk, thermal effects on material properties - flammability, indirect mechanical load (release or fall of facing etc.), and direct effects of static load. Thermal analysis is made according to STN EN 1991-1-1-2 [1]. Static analysis is made according to STN EN 1991-1-1-2 and other STN, depending on the material type.

In accordance with the procedure, specified in STN EN 1991-1-1-2, the model fire situation was determined on the basis of an estimation or calculation of fire risk. The model (normative) fire in a fire sector (FS) is determined for the model fire situation. It is always considered only for one FS in given time; in this case the entire object is one fire sector. When assessed fire resistance of a structure, calculations considered the model (normative) fire with nominal fire curves. They are defined by relations $(1-3)$.

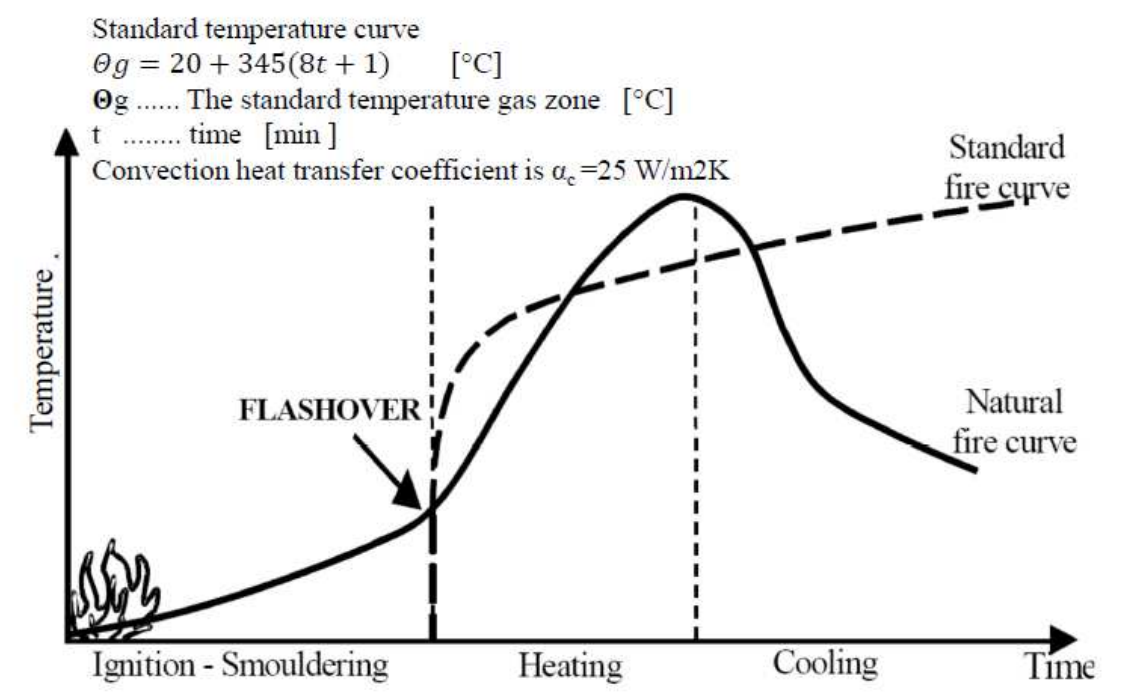

Fig. 5: Structural damage - risk of collapse - structural fire engineering concerned only with this phase of fire. 
The method of fire design or assessment of the fire barrier comprises the choice of the model fire scenario, determination of model fire, calculation of the temperature development in structural members, and calculation of the mechanical behaviour of a structure exposed to fire.

\section{The model fire and fire scenario}

The given case is based on the assumption that the fire spread and development will be evenly across the entire fire section. Simplified fire model is used. Fire is in one fire section, assuming steady temperature distribution which is a function of time. Gas temperatures will be determined on the basis of physical parameters. The density of the fire load and ventilation conditions is taken into account.

External elements have the component of radiant heat flow determined as the sum of the fire section and flames from the openings. Density of fire load = fire load per unit area. For simplified fire models $\alpha c=35\left[\mathrm{~W} /\left(\mathrm{m}^{2} \mathrm{~K}\right)\right]$.

Temperature calculation of structural elements takes into consideration their relation to the position of model fire. For external elements it is considered their exposing to fire through openings in walls and roofs. Separating walls should be considered to be exposed to fire from both sides (two different fires). If the nominal temperature curve is used, the temperature analysis is made for a given time period omitting the phase of cooling [12].

Heat load for temperature calculations gives the net heat flux on the element surface. It is defined by the sum of the heat flow transferring by convection and radiation:

$h_{\text {net }}=h_{n e t, c}+h_{n e t, r}\left[\mathrm{~W} / \mathrm{m}^{2}\right]$,

where the net heat flux transferring by convection is defined by:

$h_{n e t, c}=\alpha_{c} \cdot\left(g-\boldsymbol{\Theta}_{m}\right)\left[\mathrm{W} / \mathrm{m}^{2}\right]$,

where:

$\alpha_{c}\left[\mathrm{~W} /\left(\mathrm{m}^{2} \mathrm{~K}\right)\right]$ - heat transfer coefficient,

$\boldsymbol{\Theta}_{g}\left[{ }^{\circ} \mathrm{C}\right]$ - gas temperature near the member exposed to fire,

$\boldsymbol{\Theta}_{m}\left[{ }^{\circ} \mathrm{C}\right] \quad$ - surface temperature of member.

The net heat flux transferring by radiation is defined by:

$h_{n e t, r}=\Phi . \varepsilon_{m} . \varepsilon_{t} . \sigma .\left[\left(\boldsymbol{\Theta}_{r}+273\right)^{4}-\left(\boldsymbol{\Theta}_{m}+273\right)^{4}\right]$,

where:

$\Phi$ - positional factor,

$\varepsilon_{m}=0,8 \quad$ - surface emissivity,

$\varepsilon_{t}=1,0 \quad$ - fire emissivity,

$\sigma=5,67.10^{-8}$ - Stephan-Boltzmann constant,

$\boldsymbol{\Theta}_{r}\left[{ }^{\circ} \mathrm{C}\right] \quad$ - temperature efficiency of radiation in fire zone,

$\boldsymbol{\Theta}_{m}\left[{ }^{\circ} \mathrm{C}\right] \quad$ - surface temperature of member.

Mechanical calculation is done for the same time as used in temperature calculation; fire resistance is assessed in the following domains:

- time ${ }_{f i, d}^{t} \leq t R^{f i, r e q u},{ }$,

- strength ${ }_{f i, d, t} \leq E_{f i, d, t}$,

- temperature $\boldsymbol{\Theta}_{d} \leq \boldsymbol{\Theta}_{c r}, d$.

8. Calculation of fire resistance requirements in terms of changes in the function and fire height of the folk house

Fire resistance requirements for the fire-exposed structures in alternated buildings of I and II category are determined by calculation specified in STN 73 0802. New buildings and alternated buildings of III category are calculated according to STN 920201-2. 
Factored fire load $p_{v}=p \cdot a \cdot b$ is determined by fire load, coefficient of flammable substances, and venting coefficient. The calculation is given in [1]. Parameters $a$ and $p$ depends on the functional use of spaces; parameter $b$ depends on the geometry of windows and spaces. In dependence on calculated fire load, building's fire height, and flammability of structures, the degree of fire safety is determined and fire resistance requirements for individual fire-separating structures and supports are specified. Table 1 gives the calculation results as defined in [7] for 3 options of the use of renovated building spaces:

- 1st option includes original condition with a functional use of housing; fire height of $3 \mathrm{~m}$,

- 2nd option includes building's renovation with the functional change of the 1st floor into exhibition rooms of Hutterian culture; the attic has no functional use and it isn't open to public; fire height of $0 \mathrm{~m}$ - implemented solution,

- 3rd option includes building's renovation with the functional change of the 1st floor and attic.

At the level of both floors, there would be exhibition rooms of Hutterian culture; fire height of $3 \mathrm{~m}$. In this case, because the calculation fundamentally changes the number of people, it would be necessary to reassess existing evacuation routes. The original staircase is inadequate for planned occupancy due to its slope and width, so there would emerge the requirement for its modification; or the number of attic visitors would have to be regulated by a guide not to exceed the limit to keep evacuation safe.

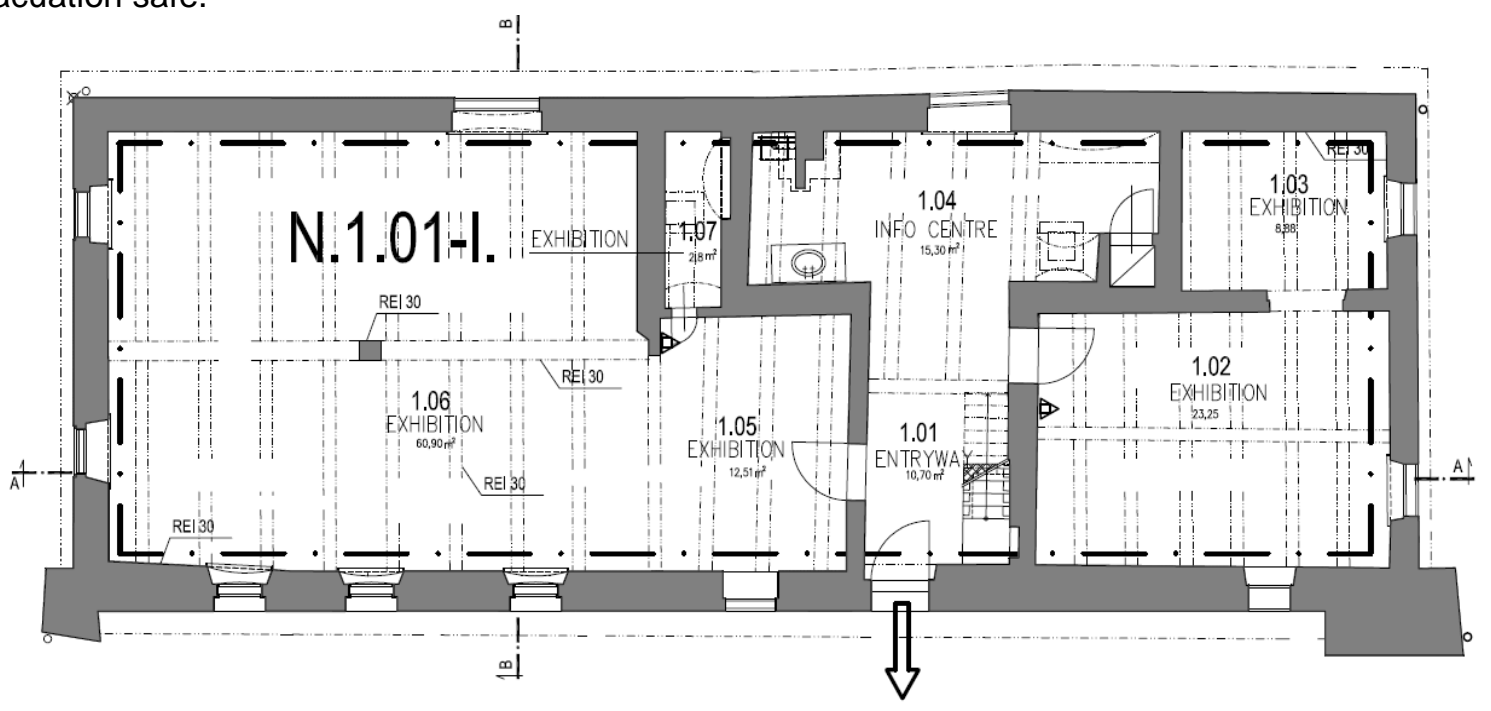

Fig. 5: Layout after the building's renovation - 1st floor plan, 2nd option [8].

Table 2: Determination of requirements for fire resistance of building structures in dependence on their functional usability and fire height.

\begin{tabular}{|c|c|c|c|c|c|c|c|c|c|}
\hline \multirow{3}{*}{$\begin{array}{l}\text { Fire } \\
\text { height }\end{array}$} & \multirow{3}{*}{ Functional usability } & \multirow{2}{*}{\multicolumn{3}{|c|}{ Fire hazard }} & \multicolumn{5}{|c|}{$\begin{array}{l}\text { Requirements for fire-separating structures } \\
\text { in combined construction system }\end{array}$} \\
\hline & & & & & \multirow{2}{*}{$\begin{array}{c}\text { walls } \\
\begin{array}{c}\text { REI } \\
\text { minutes }\end{array}\end{array}$} & \multirow{2}{*}{$\begin{array}{c}\text { ceilings } \\
\text { REI } \\
\text { minutes }\end{array}$} & \multirow{2}{*}{$\begin{array}{c}\text { roof } \\
\text { REI } \\
\text { minutes }\end{array}$} & \multirow{2}{*}{$\begin{array}{c}\begin{array}{c}\text { pillars, } \\
\text { beams }\end{array} \\
R \\
\text { minutes }\end{array}$} & \multirow{2}{*}{ SPBS } \\
\hline & & $a$ & $b$ & $\begin{array}{c}p_{v} \\
\mathrm{~kg} / \mathrm{m}^{2}\end{array}$ & & & & & \\
\hline ho $=3 \mathrm{~m}$ & $\begin{array}{l}\text { Housing } \\
\text { original function of N1.01/N2 }\end{array}$ & 1 & 0.99 & 40 & 30 & 30 & 15 & 30 & II. \\
\hline ho $=0 \mathrm{~m}$ & $\begin{array}{l}\text { Museum } \\
\text { new function of the 1st floor } \\
\text { N1.01 }\end{array}$ & 1.1 & 0.99 & 66 & 30 & 30 & 15 & 30 & II. \\
\hline ho $=3 \mathrm{~m}$ & $\begin{array}{l}\text { Museum } \\
\text { new function of the 1st floor + } \\
\text { attic N1.01/N2 }\end{array}$ & 1.1 & 0.99 & 142 & 60 & 60 & 30 & 60 & IV. \\
\hline
\end{tabular}

SPBS - Degree of fire safety of building structures; REI - Fire resistance of supporting fire-partition walls and ceilings in terms of load capacity, stability, integrity, and thermal insulation 


\section{Assessment of truss elements in terms of their mechanical fire resistance according to STN EN 1995-1-2 using the cross-section method}

For common design practice it is allowable to use simplified assessment methods. They are usually as follows: a) the cross-section method, b) the method of reduced properties.

The first one is the most preferred for its simplicity and relatively conservative approach, resulting in its wide application. Accordingly, it was applied to given structure.

The second one is principally based on the fact that charred part of evaluated cross-section is not included in resistance, i.e. the residual cross-section doesn't change its strength or stiffness properties. Charring depth is estimated from the fire duration to which an element is exposed and the corresponding rate of charring. This interface, i.e. char line position, in the majority of coniferous and deciduous trees responds to the isotherm $300^{\circ} \mathrm{C}$. After getting an effectual cross-section, the element is assessed according to [4].

The method of reduced properties works with the residual section (gained after deduction of charred layer) which considers changed strength and stiffness properties of the material on the basis of the coefficient modification. More information on the fire resistance of wooden structures and fire safety in wooden buildings is available in publication [7].

Critical load of timber truss members at the common temperature and extreme situation - fire, including tension, is shown in Tables 3 and 4 . Tables also provide unit assessment that illustrates the cross-section use during fire.

Table 3: Assessment of main load-bearing timber elements in terms of fire resistance (1st and 2nd option).

\begin{tabular}{|c|c|c|c|c|c|c|c|c|c|c|c|c|c|c|c|c|c|}
\hline No. & Member & {$\left[\begin{array}{c}b \\
{[\mathrm{~mm}}\end{array}\right]$} & $\stackrel{\mathrm{h}}{[\mathrm{mm}]}$ & $\left.\begin{array}{c}M_{y, E d} \\
{[k N m]}\end{array}\right]$ & $\begin{array}{l}M_{2, E d} \\
{[k N m]}\end{array}$ & $\begin{array}{l}\mathrm{N}_{\mathrm{Ed}}{ }^{1)} \\
{[\mathrm{kN}]}\end{array}$ & $\begin{array}{l}h_{f i} \\
{[-]}\end{array}$ & $\begin{array}{l}\mathrm{M}_{\mathrm{y}, \mathrm{Ed}, \mathrm{fi}} \\
{[\mathrm{kNm}]}\end{array}$ & $\left.\begin{array}{l}M_{2, E d f} \\
{[k N m]}\end{array}\right]$ & $\left|\begin{array}{l}\mathrm{N}_{\mathrm{Ed}, \mathrm{fi}} \\
{[\mathrm{kN}]}\end{array}\right|$ & $\begin{array}{l}1 / 2 s_{m, y, d f f}{ }^{1 / 2} \\
{[\mathrm{MPa}]}\end{array}$ & $\begin{array}{c}1 / 2 s_{m, z, d, f^{1 / 2}} \\
{[\mathrm{MPa}]}\end{array}$ & $\begin{array}{c}1 / 2 \mathrm{~s}_{\mathrm{ct}, \mathrm{o}, \mathrm{d}, \mathrm{fi}} \\
1 / 2 \\
{[\mathrm{MPa}]}\end{array}$ & \multicolumn{4}{|c|}{$\begin{array}{c}\text { Assessment } \\
\text { bend }+ \text { pressure } \\
\text { (bend+tension) }\end{array}$} \\
\hline & \multicolumn{17}{|c|}{ Fire resistance assumption: $\mathbf{R} 15$} \\
\hline 1 & rafter & 160 & 130 & $\mid-1,71$ & 0,00 & 10,79 & 0,6 & $-1,03$ & 0,00 & $-6,47$ & 4,095 & 0,000 & 0,478 & 0,21 & $<$ & 1,0 & meets \\
\hline 2 & $\begin{array}{l}\text { bottom collar } \\
\text { beam }\end{array}$ & 160 & 150 & 5,59 & 0,00 & 10,53 & 0,6 & 3,35 & 0,00 & $-6,32$ & 9,612 & 0,000 & 0,395 & 0,40 & $<$ & 1,0 & meets \\
\hline 3 & upper collar be & 160 & 140 & 0,00 & 0,00 & $-2,35$ & 0,6 & 0,00 & 0,00 & $-1,41$ & 0,000 &, 000 & 0,100 & 0,01 & $<$ & 1,0 & r \\
\hline 4 & purlin & 120 & 1 & 9 & 9 & 9 & 0,6 & 9 & 77 & 65 & 6,941 & 4,366 & 17 & 0,40 & $<$ & 1,0 & eets \\
\hline 5 & post & 120 & 150 & $-0,93$ & 0,68 & 13,47 & 0,6 & $-0,56$ & 0,41 & 8,08 & 2,935 & 2,899 & 0,818 & 0,25 & $<$ & 1,0 & meets \\
\hline 6 & brace strut & 130 & 130 & 0, & 13 & 19,65 & 0,6 & 0,08 & 1,28 & $-11,79$ & 0,537 & 8,804 & 293 & 0,44 & $<$ & 1,0 & \\
\hline & \multicolumn{17}{|c|}{ Fire resistance assumption: $\mathbf{R} 30$} \\
\hline 7 & ceiling & 200 & 250 & 6,35 & 0,63 & 0,53 & 0,6 & 3,81 & 0,38 & 0,32 & 3,454 & 0,544 & 0,011 & 0,15 & $5<$ & 1,0 & meets \\
\hline 8 & roof $g$ & 300 & 270 & 14,64 & $-0,16$ & 15,08 & 0,6 & $-8,78$ & $-0,10$ & $-9,05$ & 0,1 & 050 & 0,180 & 0,23 & $<$ & 1,0 & meets \\
\hline 9 & column & & & 0,11 & 1,30 & 55,50 & 0,6 & 0,07 & \begin{tabular}{|l|}
0,78 \\
\end{tabular} & $-33,30$ & 0,142 & 1,676 & 1,502 & 0,16 & $<$ & 1,0 & me \\
\hline
\end{tabular}

${ }^{1)}$ positive sign (+) means tensile force; negative sign (-) means compression force; ${ }^{2)}$ the average column diameter at its narrowest spot 
Table 4: Assessment of main load-bearing timber elements in terms of fire resistance (3rd option).

\begin{tabular}{|c|c|c|c|c|c|c|c|c|c|c|c|c|c|c|c|c|c|}
\hline No & Member & $\begin{array}{c}\mathrm{b} \\
{[\mathrm{mm}]}\end{array}$ & $\begin{array}{c}\mathrm{h} \\
{[\mathrm{mm}} \\
]\end{array}$ & $\begin{array}{c}\mathrm{M}_{\mathrm{y}, \mathrm{Ed}} \\
{[\mathrm{kNm}} \\
]\end{array}$ & $\begin{array}{c}\mathrm{M}_{2, \mathrm{Ed}} \\
{[\mathrm{kNm}} \\
]\end{array}$ & $\begin{array}{l}\mathrm{NEd}^{1]} \\
{[\mathrm{kN}]}\end{array}$ & $\begin{array}{l}\eta_{\mathrm{f}} \\
{[-]}\end{array}$ & $\begin{array}{c}M_{y, E d} \\
{[\mathrm{kN}} \\
\mathrm{m}]\end{array}$ & {$\left[\begin{array}{c}\mathrm{M}_{\mathbf{2}, \text { Edf }} \\
i \\
{[\mathrm{kNm}} \\
]\end{array}\right.$} & $\begin{array}{l}N_{\mathrm{Ed}, \mathrm{f}} \\
{[\mathrm{kN}]}\end{array}$ & ||$_{[\mathrm{MPa}]}^{\mid \sigma_{\text {my,dfi }}}$ & $\begin{array}{l}\mid \sigma_{m z, \mathrm{~d}, \mathrm{f}} \\
\mid \\
{[\mathrm{MPa}]}\end{array}$ & $\begin{array}{c}\mid \sigma_{c(t), 0, d, f i} \\
\mid \\
{[\mathrm{MPa}]}\end{array}$ & \multicolumn{4}{|c|}{$\begin{array}{c}\text { Assessment } \\
\text { bend+pressure } \\
\text { (bend+tension) }\end{array}$} \\
\hline & \multicolumn{17}{|c|}{ Fire resistance assumption: $\mathbf{R} 30$} \\
\hline 1 & rafter & 160 & 130 & $-1,71$ & 0,00 & 10,7 & 0,6 & $-1,03$ & 0,00 & 6,47 & 6,409 & 0,000 & 0,667 & 0,33 & $<$ & 1,0 & meets \\
\hline 2 & $\begin{array}{l}\text { bottom } \\
\text { collar beam }\end{array}$ & 160 & 150 & 5,59 & 0,00 & 10,5 & 0,6 & 3,35 & 0,00 & 6,32 & 01 & 0 & 12 & 0,60 & $<$ & 1,0 & meets \\
\hline 3 & $\begin{array}{l}\text { upper collar } \\
\text { beam }\end{array}$ & 160 & 140 & 0,00 & 0,00 & 2,35 & 0,6 & 0,00 & 0,00 & 1,41 & 0,000 & 0,000 & 0,163 & 0,01 & $<$ & 1,0 & meets \\
\hline 4 & purlin & 120 & 180 & 3,49 & 1,29 & 21,0 & 0,6 & 2,09 & 0,77 & 12,6 & 15,557 & 11,699 & 1,849 & 0,96 & $<$ & 1,0 & meets \\
\hline 5 & post & 120 & 150 & $-0,93$ & 0,68 & 13,4 & 0,6 & $-0,56$ & 0,41 & 8,08 & 7,454 & 8,269 & 1,583 & 0,65 & $<$ & 1,0 & meets \\
\hline 6 & brace strut & 130 & 130 & 0,13 & $-2,13$ & 19,6 & 0,6 & 0,08 & 1,28 & 11,7 & 1,488 & 24,387 & 2,550 & 1,26 & $<$ & 1,0 & $\begin{array}{l}\text { oesn' } \\
\text { meet }\end{array}$ \\
\hline & \multicolumn{17}{|c|}{ Fire resistance assumption: R 45} \\
\hline 7 & ceiling & 200 & 250 & 6,35 & 0,63 & 0,53 & 0,6 & 3,81 & 0,38 & 0,32 & 4,680 & 0,843 & 013 & 21 & $<$ & 1,0 & eeets \\
\hline 8 & roofg & 300 & 270 & 14,6 & $-0,16$ & 15,0 & 0,6 & $-8,78$ & $-0,10$ & 9,05 & 7,274 & 0,068 & 230 & 32 & $<$ & 1,0 & meets \\
\hline 9 & column & $d=2$ & & 0,11 & 1,30 & 55,5 & 0,6 & 0,07 & 0,78 & 33,3 & 0,225 & 2,661 & 2,045 & 0,25 & $<$ & 1,0 & meets \\
\hline
\end{tabular}

${ }^{1)}$ positive sign (+) means tensile force; negative sign (-) means compression force; ${ }^{2)}$ the average column diameter at its narrowest spot

Data in tables are calculated in accordance with the standard method specified in [5] under the conditions and relationships below.

$\eta_{f i}$ - Reducing factor for combined loads. As simplification it is possible to use value 0.6 (according to STN EN 1995-1-2).

Material characteristics consider:

$k_{f i} \quad$ - coefficient of arown wood; $k_{f i}=1.25$,

$k_{\text {mad fi }}$ - modifv factor in fire: $\mathrm{k}_{\mathrm{fi}}=1.0$.

$\gamma_{M, f i} \quad$ - partial coefficient of wood reliability in fire; $\gamma_{M, f i}=1.0$.

Calculation of charrina depth considers:

$\beta_{n}$ - designed theoretical char rate under normalized fire; $\beta_{n}=0,8 \mathrm{~mm} / \mathrm{min}$ (for grown wood),

$k_{n}$ - coefficient for non-protected surfaces; $k_{n}=1,0$,

$d_{0}$ - layer thickness with assumed zero strength and stiffness; $d_{0}=7 \mathrm{~mm}$.

The effective cross-section entering the assessment of mechanical resistance is determined according to Figure 6, where the proposed theoretical charring speed is:

$d_{\text {char } n}=\beta_{n} t$,

and the effective charring depth is:

$d_{\text {eff }}=d_{c h a r, n} t+k_{0} d_{0}$.

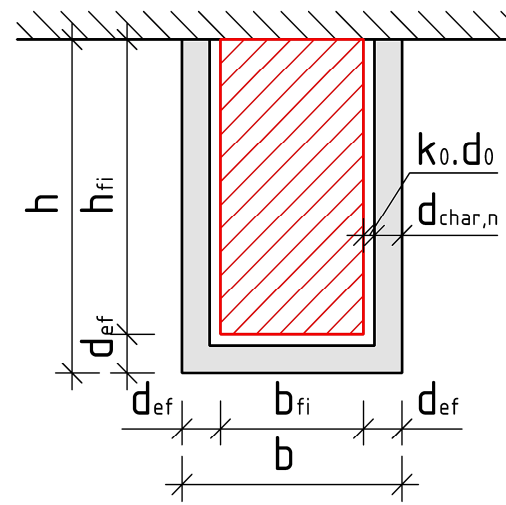

Fig. 6: Definition of the effective and residual cross-section exposed to fire on three sides. 
Table 3 evaluates fire resistance of existing load-bearing structures of the 1 st option in their original and functional use. It also evaluates the 2 nd option, where there is a functional change into a museum on the 1st floor and the roof space is not used. In these situations, all timber structural elements meet the required fire resistance without additional construction works.

Table 4 evaluates fire resistance of existing load-bearing structures of the 3rd option with the change of the 1st floor and roof space into a museum. Fire hazard in the building has fundamentally increased. Requirements for supporting roof structures as well as the ceiling have risen; they are above the current fire resistance of the ceiling, pillars, purlins, and struts. In this case, it would be necessary for the additional elements to be fire-protected with coating or tiles.

\section{Conclusion}

Optimization of the planned function and its extent in the assessed building made it possible to implement fire protection without further modifications to the original structures. The load-bearing structure retains its static load capacity even when loaded critically during fire, as the charred crosssection proved. It seems to be an ideal solution from the view of building conservation because the truss structure remains original. It preserves the authenticity of all roof members, which is of great importance to the monument preservation.

\section{Acknowledgement}

The results presented in this work were obtained with the support of the grant project VEGA 1/0945/16 (KEGA 041ŽU - 4/2014).

\section{References}

[1] STN EN 1991-1-1, Eurocode 1: Load of structures - Part 1 - 1, SUTN, Bratislava 2007.

[2] STN EN 1991-1-3, Eurocode 1: Load of structures - Part 1 - 3, SUTN, Bratislava 2007.

[3] STN EN 1991-1-4, Eurocode 1: Load of structures - Part 1 - 4, SUTN, Bratislava 2007.

[4] STN EN 1995-1-1 + A1, Eurocode 5: Design of wooden structures - Part 1 - 1: Generally General rules and rules for buildings. SUTN, Bratislava, 2008.

[5] STN EN 1995-1-2, Eurocode 5: Design of wooden structures - Part 1 - 2: General rules - Design of structures for fire effect. SUTN, Bratislava, 2008.

[6] STN EN 338: Construction wood. Strength classes. SUTN, Bratislava, 2010.

[7] STN 73 0802: Fire safety of buildings. Common provisions. SUTN, Bratislava, 2011.

[8] Project of reconstruction of the Hutterian House in the village of Vel'ké Leváre. Building design and layout by Ing. Marta Pichová and Ing. Vlasta Viglášová; fire solution by Ing. Agnes Iringová.

[9] ĎURIAN, K. - KRUŠINSKÝ, P. - KORENKOVÁ, R. - ZACHAROVÁ, D.: Self-governing region of Žilina - historic trusses (in Slovak). In: Fireco 2013, X. international conference on fire protection, Trenčín, Slovak Republic, 2. - 3. May 2013, proceedings. Bratislava, Požiarnotechnický a expertízny ústav MV SR, 2013, p. 35 - 45.

[10] LOKAJ, A. et al.: Wooden houses and structures, Volume I. and II. (in Czech). CERM, Brno, 2010.

[11] Statute 133/2013 Code on building products and amendments to certain statutes.

[12] MAKOVICKÁ OSVALDOVÁ, L. - GAŠPERCOVÁ, S.: The evaluation of flammability properties regarding testing methods. In: Civil and Environmental Engineering : scientific technical journal. ISSN 1336-5835, Vol. 11, No. 2 (2015), p. 142 - 146.

[13] STN 73 0821: Fire protection of buildings. Fire resistance of engineering structures. 